\title{
ПСИХОЛОГІЧНІ ОСОБЛИВОСТІ СПРИЙНЯТТЯ РАДІАЦІЙНОГО РИЗИКУ
}

УДК: 159.923.072.42:612.821:614.8.026.1:614.876

\section{Гресъко Марина Володимирівна}

\author{
Молодший науковий співробітник відділу радіа - \\ иійної психоневрологї Державної установи \\ "Національний науковий иентр радіаційної меди- \\ ияни Національної академії медичних наук Украї- \\ ни», м. Київ (Украӥна)
}

\begin{abstract}
Анотація. В статті проведено аналітичний огляд психологічних властивостей радіаційного впливу, перераховані фактори посилюючі неадекватне сприйняття радіаційної загрози. Визначенні суб'єктивні особливості сприйняття радіаційного ризику та вивчено місие ризику радіаџійної загрози серед інших вітальних небезпек у віддалений період після аварії на ЧАЕС. Виявлено високий відсоток осіб з гіпертрофованим сприйняттям радіаційної загрози серед УЛНА та евакуйованих із зони відчуження, щзо свідчить про актуальність для них таких стресових подій в їхньому житті, як катастрофа на ЧАЕС та евакуація навіть через 31 рік після радіаційного інцииденту. Вперше проведено оцінку сприйняття радіаційної загрози учасниками ATO.
\end{abstract}

Ключові слова: сприйняття радіаційної загрози, учасники ліквідації наслідків аварії на ЧАЕС, учасники АТО.

Постановка проблеми. Землетрус в Японії в 2011 році спричинив нову хвилю побоювань відносно безпеки атомних електростанцій. На теперішній час приблизно 20\% комерційних ядерних реакторів в світі розташовані в сейсмічно активних зонах. 32014 року на Сході України проводиться антитерористична операція (АТО), на їі території знаходиться декілька об'єктів з відкритими джерелами іонізуючого випромінювання, крім того, поблизу знаходиться найбільша в Свропі атомна електростанція (Запорізька АЕС). Загроза злочинних діянь 3 використанням джерел іонізуючого випромінювання 3 новою силою піднімає питання психологічних особливостей сприйняття радіаційної загрози, як у учасників ліквідації радіаційних надзвичайних ситуацій, так і в осіб, які беруть участь в АТО. 
Актуальність даного дослідження обумовлена також високою соціальноекономічною значимістю проблеми в сучасному суспільстві та потребою в диференційованому підході до розуміння цього феномену, який є особливо важливим при виборі мішеней психокорекційної та психотерапевтичної роботи.

Аналіз останніх досліджень та публікацій. Радіаційний вплив представляє собою об'єктивну дійсність. Однак, враховуючи його психологічні властивості, зрозуміло, що нормальний процес його сприйняття та розгортання на цій основі ефективної пристосувальної діяльності неможливий та у дорослої здорової особистості в онтогенезі не формується. Внаслідок відсутності сенсорного сприйняття небезпеки, не формується відчуття. Неможливість співвідношення діючої реальності з образами минулого досвіду перешкоджає опредметненню образа.

В результаті структура сприйняття викривляється, образ радіаційної загрози не має цілісності, константності, набуває випадковий та індивідуалізований характер, витісняється у підсвідоме; або, навпаки, є надмірно опосередкованим змістом колективної свідомості, соціумом, включаючи мінливість зовнішньої інформації, структуру довіри до неї. Саме цей феномен (викривлення структури сприйняття) порушує процес адаптації, сприяє розвитку стресу та лежить в основі безумовної патогенності радіаційних аварій для пси- хічної сфери людини $[7 ; 11]$.

Специфіка суспільного сприйняття ризику обумовлена психологічними факторами, в залежності від яких ризик постає більш або менш значущім. До факторів, які посилили сприйняття радіаційної загрози після Чорнобильської аварії можна віднести:

- потенційну небезпеку - визначена спочатку територія забруднення неодноразово розширювалась, наявність радіонуклідів 3 тривалим періодом напіврозпаду;

- обізнаність про ризик - до аварії був відомий тільки по інформації вражаючої дії ядерної зброї;

- розуміння механізмів дії - дію малих доз опромінення на людину досі вивчають;

- можливість індивідуального контролю - немає сенсорного сприйняття;

- добровільність сприйняття ризику недобровільний для населення та більшості ліквідаторів;

- віддалені наслідки - наслідки радіаційного опромінення можуть проявитись через багато років, а за рахунок ембріотоксичних та генетичних ефектів і через покоління;

- довіра відповідальним інститутам недовіра властям, підірваний авторитет спеціалістів;

- участь засобів масової інформації великий потік неперевірених матеріалів про масштаби аварії та пошкоджуючу дію радіаційного опромінення;

- рівень аварії - максимальний рівень 
по шкалі INES (International Nuclear Event Scale - Міжнародна шкала ядерних подій);

- вигоди від ризику - на думку постраждалих пільги та компенсації неадекватні збитку;

- причина - промислова діяльність держави, втрата контролю над процесами, які вважались безпечними.

Отже сприйняття ризику іонізуючого випромінювання $є$ складним процесом, який вносить свій вклад в формування дистресу після радіаційних інцидентів.

Перші дослідження сприйняття радіаційної загрози були проведені ще в дев'яності роки. Так в дослідженнях українського вченого В. А. Моляко більшість респондентів найбільш небезпечним наслідком Чорнобильської аварії назвали можливість захворювання від радіації (69\% дорослі, 745 студенти, 51\% школярі) [3; 4]. В дослідженні проведеному Інститутом соціології РАН в 1991 році в п'яти областях Росії, які зазнали радіоактивного забруднення, виявлено, що самим потужним по інтенсивності переживанням при згадуванні про АЕС є відчуття небезпеки для здоров'я $(90,9 \%)$ [8].

Учасники ліквідації аварії на ЧАЕС 1986-87 років, в дослідженнях Чинкіної О. В., радіаційний ризик поставили на перше місце 3 великим відривом від інших вітальних небезпек. Також було зазначено, що дезадаптуючу роль грає і оцінка своєї участі в аварії як недобровільної (81\%), що є базою для сприйняття себе в якості «жертви» [10].

Дослідження національного інституту психічного здоров'я Японії сумісно з медичним університетом Фукусіми показали наявність позитивного зв'язку між дистресом та неадекватним сприйняттям радіаційної загрози, а також асоціативний зв'язок між стурбованістю радіаційними ризиками (як безпосереднього так і відстроченого та генетичного характеру) та наявністю психологічних розладів серед евакуйованих в зв'язку з ядерною катастрофою на АЕС «Фукусіма» [14].

Е. Дж. Бромет (Bromet E. J.) та Дж. М. Хавенаар (Havenaar J. М.) відмічають залежність психологічних розладів від неадекватного сприйняття радіаційної загрози та описують ознаки депресії, тривоги та посттравматичного стресового розладу серед постраждалих від радіаційних аварій [12].

Дослідження сприйняття радіаційного ризику спеціалістами та населенням, вченими 3 Бельгійського центру ядерних досліджень показало, що сприйняття медичного та природного опромінення серед експертів вище, ніж серед населення, в той час як оцінка небезпеки ядерних відходів та аварій на ядерних установках серед експертів нижча ніж серед населення [13].

В дослідженнях Тарасюк О. Є. та співавторів опитування молоді та батьків різних регіонів України показало, що навіть жителі умовно чистого Донецького регіону значно частіше суб'єктивно оцінювали радіаційний 
стан території на якій вони зараз мешкають, як «дуже брудний». Найбільш небезпечним видом опромінення опитані вважають викиди діючих АЕC та радіонукліди чорнобильського походження в той час, як небезпеку отримати опромінення під час польоту літаком, вони ставлять на 11 рангове місце, а від радону у повітрі приміщень на 9 з 11 факторів [9].

В дослідженнях Прилипко В. А. та співавторів серед 31 фактору ризику для здоров'я і життя, радіаційний залишається головним, а забруднення оточуючого середовища i, як наслідок, продуктів харчування радіоактивними ізотопами, молодь оцінила як «достатньо велику» небезпеку [6].

В 2005 році було проведено анкетування з метою оцінки пріоритетних факторів ризику щодо впливу на здоров'я, серед населення Житомирської, Київської, Дніпропетровської та Запорізької областей, інститутом гігієни та медичної екології сумісно з агенцією з радіаційного захисту Швеції. Серед 16 запропонованих факторів ризику (паління, алкоголь, наркотики, подорожі літаком та ін.) перше місце респондентами було віддано «чорнобильському» опроміненню, а техногенно підсилені джерела природного походження віднесені на 7 місце. «Чорнобильська радіація» викликає більшу стурбованість щодо стану власного здоров'я серед населення не тільки на постраждалих територіях, але і «чистих» регіонів України в порівнянні з іншими джерелами опромінення [5].
Буртова Е. Ю. та співавтори обстежили населення прибережної зони річки Теча із зони Східно-Уральського радіоактивного сліду. Респонденти основними проблемами називали власне здоров'я $(55,4 \%)$ та радіаційну небезпеку (50\%). Причому оцінка рівня кортизолу в основній групі була достовірно вища, у порівнянні з контролем, що свідчіть про напруження систем адаптації та виражений дистрес. Суб'єктивна оцінка значущості радіаційної загрози «як особо значуща подія» серед осіб 3 діагнозом «хронічна зміна особистості після переживання катастрофи» була виявлена у $48,8 \%$ опитаних [1].

В дослідженнях Дворянчикова Н. В. та співавторів, військовослужбовців які постійно працюють 3 джерелами іонізуючого випромінювання, лише $29 \%$ респондентів оцінили рівень отриманого опромінення об'єктивно, тоді як 71\% переоцінили рівень опромінення [2].

Отже дослідження свідчать, що в після аварійний період учасники ліквідації наслідків аварії на ЧАЕС, як і жителі радіаційно забруднених територій, мають ознаки психоемоційного напруження та психічної дезадаптації.

Мета дослідження: Визначення суб'єктивних особливостей сприйняття радіаційного ризику та визначення його місця серед інших небезпек у віддалений період після аваpiї на ЧАЕС.

Виклад основного матеріалу дослідження. Опитування пройшли 122 учасника 
(1 - група) ліквідації наслідків аварії на ЧАЕС (УЛНА), вік на момент обстеження $54,50 \pm 4,22,3$ дозою опромінення $15,33 \pm 12,77$ с3в; 76 УЛНА на ЧАЕС, які до того ж були евакуйовані із зони відчуження (2 - група) вік на момент обстеження 55,53 $\pm 3,61,3$ дозою

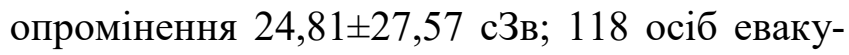
йованих із зони відчуження (3 - група) вік на момент обстеження $58,42 \pm 3,71,3$ дозою опромінення 5,42 $\pm 2,64$ с3в із рандомізованої вибірки осіб, які знаходяться на обліку в клінікоепідеміологічному реєстрі (КЕР) Державної установи «Національний науковий центр радіаційної медицини Національної академії медичних наук України (ННЦРМ). Групу порівняння склали 84 особи (4 - група) у віці на момент обстеження 51,06 $\pm 3,37$ роки, які не приймали участі в ліквідації наслідків аварії на ЧАЕС. Також було опитано 81 учасника ATO (5 - група) вік на момент обстеження $32,32 \pm 8,89$, які проходили лікування і реабілітацію у відділенні радіаційної психоневрології клініки ННЦРМ.

Для опитування був використаний модифікований соціально-психологічний опитувальник (Joint Study Project, 1993). Питання опитувальника включали розділи: загальні відомості, звички та оцінка здоров'я, поточні турботи та проблеми, анкета оцінки небезпек, ризик та пільги, інформація та знання, аспекти переселення.

Значна частина респондентів основних груп та групи порівняння, вперше дізнавшись про Чорнобильську аварію, були дуже сильно занепокоєні тим, що сталось (I - 47,37\%, II $59,38 \%$, III - 58,70\%, IV - 46,75\%). Однак в групі евакуйованих із зони відчуження достовірно менший відсоток осіб, які не були занепокоєні зовсім, у порівнянні з УЛНА та групою порівняння $(\mathrm{p}<0,01)$. На теперішній час респонденти основних груп непокояться 3 цього приводу так само, на відміну від групи порівняння де хвилювання набагато менші.

В усіх групах опитаних дуже високій відсоток осіб, які відчували тривогу за результат аварії на четвертому енергоблоці ЧАЕС (I - 88,18\%, II - 90\%, III - 93,48, IV - 76,92\%), однак в групі порівняння таких осіб достовірно менше (I та II $-p<0,05$, III $-p<0,01$ ). В усіх групах значна частина осіб непокоїться з приводу аварії на AЕC Фукусіма-1 в Японії (I 38,94\%, II - 46,77\%, III - 42,39, IV - 45,57\%). УЛНА доволі сильно занепокоєні і з приводу можливих негараздів на ЧАЕС на теперішній час (I - 40,71\%, II - 37,70\%), евакуйовані та респонденти групи порівняння 3 цього приводу непокояться лише трохи (III - 40,86\%, IV 44,30\%). Отримані результати можуть свідчити про тривожну свідомість $з$ приводу радіаційної небезпеки у населення України, де сталась найпотужніша радіаційна аварія, якій Міжнародна агенція з ядерної енергії присвоїла найвищий 7 рівень небезпеки.

В основних групах обстежених достовірно більша кількість осіб у порівнянні з групою порівняння, які вважають Чорнобильську 
аварію та евакуацію із зони відчуження причиною свого психологічного стресу (I $55,75 \%$, II - 78, 13\%, III - 77,42\%, IV -25,32\%).

Респонденти основних груп достовірно більше занепокоєні впливом радіації на здоров'я в зв'язку з Чорнобильською аварією у порівнянні з групою порівняння (I та II $\mathrm{p}<0,001$, III - $\mathrm{p}<0,01)$. В основних групах достовірно більше осіб чули, що після Чорнобильської аварії, люди у віці 30-40 років раптово помирали без видимої причини (I $70,54 \%$, II - 74,19, III - 72,22\%, IV -41,77\%).

УЛНА та евакуйовані доволі сильно занепокоєні соціальними змінами (I - 32,74\%, кою аварією (I - 44,25\%, II - 38,10, III $40,86 \%)$, в той час як в групі порівняння негативними соціальними змінами занепокоєні дуже небагато, а економічними декілька.

Найгіршим наслідком атомної аварії УЛНА вважають ризик для здоров'я, радіаційне зараження та невпевненість в майбутньому, в той час як евакуйовані на трете місце ставлять переселення. В групі порівняння на першому місці знаходиться радіаційне зараження (табл. 1).

Основним негативним наслідком Чорнобильської аварії всі опитані називають хвилювання за здоров'я. Занепокоєність 3 приво-

Табличя 1.

\section{Відповіді на питання: «Який з нижче наведених варіантів є, найгіршим наслідком атомної аварії?»}

\begin{tabular}{|l|c|c|c|c|}
\hline & $\begin{array}{c}\text { УЛНА } \\
(\mathrm{n}=113)\end{array}$ & $\begin{array}{c}\text { УЛНА - ева- } \\
\text { куйовані } \\
(\mathrm{n}=64)\end{array}$ & $\begin{array}{c}\text { Евакуйовані } \\
(\mathrm{n}=92)\end{array}$ & $\begin{array}{c}\text { Група порів- } \\
\text { няння } \\
(\mathrm{n}=79)\end{array}$ \\
\cline { 2 - 5 } & $\begin{array}{c}\text { Відносна час- } \\
\text { тота (\%) }\end{array}$ & $\begin{array}{c}\text { Відносна час- } \\
\text { тота (\%) }\end{array}$ & $\begin{array}{c}\text { Відносна час- } \\
\text { тота (\%) }\end{array}$ & $\begin{array}{c}\text { Відносна } \\
\text { частота (\%) }\end{array}$ \\
\hline Переселення & 3,54 & 7,81 & 14,13 & 6,33 \\
\hline Невпевненість в майбутньому & 15,04 & 14,06 & 4,35 & 10,13 \\
\hline Втрата друзів & - & - & 1,09 & - \\
\hline Ризик для здоров'я & 48,67 & 45,31 & 47,83 & 27,85 \\
\hline Відчуття безпорадності & 3,54 & 3,13 & 5,43 & 8,86 \\
\hline Радіаційне зараження & 20,35 & 26,56 & 26,09 & 40,51 \\
\hline Медичні обстеження & 2,65 & - & - & - \\
\hline Втрата особистого майна & - & - & - & 1,27 \\
\hline Втрата земельної ділянки & - & - & - & - \\
\hline Втрата роботи & - & - & 1,09 & - \\
\hline Соціальна руйнація & 5,31 & 1,56 & - & 2,53 \\
\hline Інше & 0,88 & 1,56 & - & 2,53 \\
\hline
\end{tabular}

II - 35,94\%, III - 33,70\%) та негативними економічними змінами в зв'язку з Чорнобильсь- ду води та продуктів називають частіше УЛНА. Вимушену зміну образу життя, втрату 
особистого майна, недоброзичливість інших, надмірне занепокоєння, розлуку з друзями та небажання переїжджати, як негативний наслідок аварії на ЧАЕС частіше називають опитані II та III групи, які були евакуйованими. пі та 12,36\% в III групі, покращили свої житлові умови.

В групі порівняння достовірно менше осіб, які слідкують за новинами та інформацією про Чорнобильську аварію по радіо та те-

Табличя 2.

Відповіді на запитання: «Які негативні наслідки Чорнобильської аварії для Вас та Вашої сім'ї?»

\begin{tabular}{|l|c|c|c|c|}
\hline & $\begin{array}{c}\text { УЛНА } \\
(\mathrm{n}=107)\end{array}$ & $\begin{array}{c}\text { УЛНА - } \\
\text { евакуйова- } \\
\text { ні } \\
(\mathrm{n}=61)\end{array}$ & $\begin{array}{c}\text { Евакуйовані } \\
(\mathrm{n}=88)\end{array}$ & $\begin{array}{c}\text { Група по- } \\
\text { рівняння } \\
(\mathrm{n}=67)\end{array}$ \\
\cline { 2 - 5 } & $\begin{array}{c}\text { Відносна } \\
\text { частота (\%) }\end{array}$ & $\begin{array}{c}\text { Відносна } \\
\text { частота (\%) }\end{array}$ & $\begin{array}{c}\text { Відносна } \\
\text { частота (\%) }\end{array}$ & $\begin{array}{c}\text { Відносна } \\
\text { частота } \\
(\%)\end{array}$ \\
\hline Занепокоєність з приводу продуктів & 37,78 & 30,00 & 31,03 & 23,88 \\
\hline Занепокоєність з приводу води & 44,86 & 28,33 & 31,03 & 19,40 \\
\hline Небажання переселятися & 11,21 & 19,67 & 23,86 & 10,45 \\
\hline Надмірна увага & 0,93 & 1,67 & - & 2,99 \\
\hline Знецінення власності & 5,61 & 11,48 & 11,36 & - \\
\hline Розлука з друзями & 12,15 & 26,23 & 25,00 & 2,99 \\
\hline Надмірне занепокоєння & 6,54 & 18,03 & 19,32 & 8,96 \\
\hline Хвилювання за здоров'я & 80,37 & 81,97 & 84,09 & 48,53 \\
\hline Недоброзичливість інших людей & 6,54 & 24,59 & 18,18 & - \\
\hline Вимушена зміна образу життя & 23,36 & 55,74 & 47,19 & 13,43 \\
\hline Втрата особистого майна & 5,61 & 34,43 & 30,68 & 5,97 \\
\hline Втрата земельної ділянки & 1,87 & 14,75 & 11,36 & 1,49 \\
\hline Таких немає & 4,67 & 8,33 & 2,27 & 20,90 \\
\hline
\end{tabular}

Більша частина опитаних не бачить позитивних моментів Чорнобильської аварії, хоча значна частина з опитаних II $(57,63 \%)$ та III групи (65,38\%) задоволені матеріальною компенсацією за втрачене майно в результаті аваpiï на ЧАЕС; а 22,01\% в I групі, 32,2\% в II гру- лебаченню доволі уважно (II $-\mathrm{p}<0,01$, III $\mathrm{p}<0,05)$. При цьому опитані всіх груп рідко говорять про аварію з членами родини та друзями (I - 78,38\%, II - 64,06\%, III - 63,74\%, IV $-82,43 \%)$.

До того як сталась Чорнобильська аварія УЛНА та опитані групі порівняння знали 
Табличя 3.

\section{Відповіді на питання: «Які позитивні наслідки Чорнобильської аварії для Вас та Ва-} шої сім'ї?»

\begin{tabular}{|c|c|c|c|c|}
\hline & $\begin{array}{l}\text { УЛНА } \\
(\mathrm{n}=107)\end{array}$ & $\begin{array}{c}\text { УЛНА - } \\
\text { евакуйовані } \\
(n=62)\end{array}$ & $\begin{array}{c}\text { Евакуйовані } \\
(n=87)\end{array}$ & $\begin{array}{c}\text { Група порі- } \\
\text { вняння } \\
(n=69)\end{array}$ \\
\hline & $\begin{array}{c}\text { Відносна } \\
\text { частота (\%) }\end{array}$ & $\begin{array}{c}\text { Відносна } \\
\text { частота }(\%)\end{array}$ & $\begin{array}{c}\text { Відносна } \\
\text { частота (\%) }\end{array}$ & $\begin{array}{c}\text { Відносна } \\
\text { частота }(\%)\end{array}$ \\
\hline Покращення медичної допомоги & 26,17 & 19,35 & 22,99 & 15,94 \\
\hline Підвищення життєвого рівня & 4,67 & 1,61 & 9,20 & 2,90 \\
\hline Більше уваги 3МІ & 1,87 & 3,23 & 4,60 & 4,35 \\
\hline Зустріч з новими людьми & 4,67 & 4,84 & 19,54 & 1,45 \\
\hline $\begin{array}{l}\text { Покращення соціально-побутових умов прожи- } \\
\text { вання }\end{array}$ & 3,74 & 6,45 & 8,05 & - \\
\hline Матеріальна компенсація & 13,08 & 12,90 & 17,24 & - \\
\hline Контроль спеціалістами даної території & 7,48 & 6,45 & 5,75 & 5,80 \\
\hline Зацікавленість закордонних країн & 5,61 & 1,61 & 1,15 & 2,90 \\
\hline Покращення комунальних послуг & - & 3,23 & 3,45 & 1,45 \\
\hline Краща школа, ВУЗ & - & 3,32 & 5,75 & - \\
\hline Покращення забезпечення продуктами & - & - & 3,45 & 1,45 \\
\hline Покращення робочої ситуації & - & 1,61 & 4,60 & 1,45 \\
\hline Таких немає & 58,88 & 61,29 & 51,72 & 71,43 \\
\hline
\end{tabular}

про атомні станції, дуже небагато (I - 45,54\%, IV - 38,67\%), ліквідатори - евакуйовані знали дещо (34,92\%), евакуйовані із зони відчуження не знали нічого (40,91\%). Опитані всіх груп

Таблиия 4.

\section{Відповіді на питання: «Щоб Ви зробили, щоб захистити себе від радіації, якби поряд сталась ядерна аварія?»}

\begin{tabular}{|l|c|c|c|c|}
\hline & $\begin{array}{c}\text { УЛНА } \\
(\mathrm{n}=112)\end{array}$ & $\begin{array}{c}\text { УЛНА - ева- } \\
\text { куйовані } \\
(\mathrm{n}=63)\end{array}$ & $\begin{array}{c}\text { Евакуйовані } \\
(\mathrm{n}=87)\end{array}$ & $\begin{array}{c}\text { Група порі- } \\
\text { вняння } \\
(\mathrm{n}=73)\end{array}$ \\
\cline { 2 - 5 } & $\begin{array}{c}\text { Відносна } \\
\text { частота (\%) }\end{array}$ & $\begin{array}{c}\text { Відносна } \\
\text { частота (\%) }\end{array}$ & $\begin{array}{c}\text { Відносна } \\
\text { частота (\%) }\end{array}$ & $\begin{array}{c}\text { Відносна } \\
\text { частота (\%) }\end{array}$ \\
\hline Негайно залишив місцевість & 48,21 & 53,79 & 50,75 & 36,99 \\
\hline Попередив сім'ю та сусідів & 68,75 & 73,02 & 78,16 & 71,23 \\
\hline Зв'язався з лікарем та лікарнею & 8,04 & 6,35 & 19,54 & 8,22 \\
\hline Був би обережним з їжею та водою & 35,71 & 39,68 & 55,17 & 23,29 \\
\hline Зібрав людей на відкритій місцевості & 1,79 & 1,59 & 2,30 & 1,37 \\
\hline Спробував отримати більше інформації & 46,43 & 39,68 & 43,68 & 38,36 \\
\hline Слідкував би за інформаціюю в ЗМІ & 48,21 & 49,21 & 58,62 & 42,47 \\
\hline Залишався б у приміщенні та очікував інформації & 18,75 & 44,44 & 54,02 & 31,51 \\
\hline Помився та виправ білизну & 17,86 & 30,16 & 31,03 & 10,96 \\
\hline Купив дозиметр & 25,89 & 20,63 & 19,54 & 23,29 \\
\hline Не пустив дітей до школи & 37,50 & 58,73 & 67,82 & 32,88 \\
\hline Прийняв йод & 24,11 & 52,38 & 66,52 & 10,96 \\
\hline Провітрив приміщення & 0,90 & 1,59 & 2,30 & - \\
\hline Прийняв алкоголь & 7,14 & 6,35 & 3,45 & 2,74 \\
\hline Закрив двері та вікна & 49,11 & 66,67 & 80,46 & 30,14 \\
\hline
\end{tabular}


доволі погано знайомі з питаннями радіації та радіоактивного забруднення (I - 42,24\%, III 43,18\%, IV - 44,00\%), окрім ліквідаторів - евакуйованих, які з питаннями радіоактивного забруднення знайомі доволі добре (38,10\%). Це пояснюється достовірно більшою кількістю осіб, які працювали на самій Чорнобильській станції до аварії ( $<<0,001)$. При цьому достовірно більше осіб хоче покращити свої знання 3 питань іонізуючого випромінювання в групі порівняння (I - 25,89\%, II - 17,74\%, III $31,46 \%$, IV - 48,00\%).

У випадку ядерної аварії опитані діяли б майже однаково: закрили б вікна та двері; попередили б сім'ю та сусідів; не пустили дітей до школи, однак ліквідатори першої та другої групи та особи групи порівняння негайно б залишили місцевість, що могло б спричинити додаткове опромінення. В групі порівняння та серед УЛНА достовірно менше осіб, які б для захисту від радіації прийняли б йод ( $<<0,001)$ (табл. 4).

УЛНА вважають, що турбуватись про постраждалих від аварії на ЧАЕС мають в першу чергу центральна влада (I - 91,15\%, II $89,06 \%$, III - 81,52, IV - 84,42\%), беруть на себе відповідальність лише $14,16 \%$ серед УЛНА, 23,44\% серед УЛНА - евакуйованих, $27,17 \%$ серед евакуйованих та $5,19 \%$ серед групи порівняння.

Покращити ситуацію викликану Чорнобильською аварією може в першу чергу центральна влада, вважають УЛНА (I -
$50,45 \%$, II - 56,45\%), евакуйовані та опитані 3 групи порівняння називають спеціалістів 3 радіації (III - 47,77\%, IV - 38,35\%).

Соціальну реабілітацію в уражених районах УЛНА вбачають в першу чергу в покращенні медичної допомоги та більших фінансових компенсаціях. Всі інші опитані окрім покращення медичного обслуговування, бажають повного знезараження та розвитку спеціальних інститутів, які надають соціальну та психологічну допомогу.

Ідея можливого переселення викликає доволі сильний стрес у опитаних всіх груп (I $36,79 \%$, II - 49,21\%, III - 45,65\%, IV $36,71 \%$ ), однак в групі контролю достовірно більше осіб, у яких психологічного дискомфорту зовсім не має $(\mathrm{p}<0,01)$.

Постраждалі II та III групи оцінюють свою життєву ситуацію після евакуації із зони відчуження частіше, як «декілька гіршу, ніж раніше» (II - 38,33\%, III - 34,09\%). В другій групі найбільш негативними аспектами свого переселення називають: невпевненість в майбутньому $(50,0 \%)$ та ризик для здоров'я $(24,19 \%)$, в третій групі навпаки $(19,10 \%$ та 47,19\%). Найбільш позитивним аспектом пов'язаним 3 переселенням постраждалі обох груп називають, зниження ризику опромінення (II $-65,08 \%$, III - 60,92\%).

Взагалі УЛНА та евакуйовані вважають, що піддались доволі великому ризику в зв'язку 3 Чорнобильською аварією (I 46,43\%, III - 54,84\%), ліквідатори, які до того 
ж були і евакуйованими вважають, що зазнали дуже великого ризику $(43,75)$, а респонденти групи порівняння - в якійсь мірі (40,26\%). Однак в групі контролю, в порівнянні з основними групами, достовірно більше $(\mathrm{p}<0,001)$ осіб, які вважають, що зовсім не піддавались такому ризику.

В групі порівняння достовірно $(\mathrm{p}<0,001)$ менше осіб 3 гіпертрофованим сприйняттям радіаційної загрози, порівняно 3 основними групами. Найбільший відсоток респондентів 3 гіпертрофованим сприйняттям

Табличя 5.

\section{Порівняльна характеристика рангових місць анкети небезпек}

\begin{tabular}{|c|c|c|c|c|c|}
\hline Фактори & $\begin{array}{l}\text { УЛНА } \\
(n=95)\end{array}$ & $\begin{array}{c}\text { УЛНА - } \\
\text { евакуйова- } \\
\text { ні } \\
(\mathrm{n}=58)\end{array}$ & $\begin{array}{c}\text { Евакуйо- } \\
\text { вані } \\
(n=80)\end{array}$ & $\begin{array}{c}\text { Група по- } \\
\text { рівняння } \\
(\mathrm{n}=71)\end{array}$ & $\begin{array}{c}\text { Учасни- } \\
\text { ки AТО } \\
(n=59)\end{array}$ \\
\hline & $\begin{array}{l}\text { Рангове } \\
\text { місце }\end{array}$ & $\begin{array}{l}\text { Рангове } \\
\text { місце }\end{array}$ & $\begin{array}{l}\text { Рангове } \\
\text { місце }\end{array}$ & $\begin{array}{l}\text { Рангове } \\
\text { місце }\end{array}$ & $\begin{array}{l}\text { Рангове } \\
\text { місце }\end{array}$ \\
\hline Злочини, пов'язані з насиллям & 18 & 18 & 19 & 18 & 20 \\
\hline Транспортний рух & 16 & 14 & 16 & 19 & 5 \\
\hline Нещасний випадок на роботі & 25 & 28 & 28 & 20 & 23 \\
\hline Нещасний випадок у побуті & 29 & 27 & 27 & 27 & 25 \\
\hline Вживання алкоголю & 31 & 31 & 30 & 31 & 31 \\
\hline Куріння & 30 & 30 & 29 & 29 & 28 \\
\hline Використання ліків & 26 & 24 & 26 & 30 & 30 \\
\hline Вживання наркотиків & 28 & 29 & 31 & 26 & 27 \\
\hline Нестача лікарів & 20 & 19 & 24 & 22 & 18 \\
\hline Національні конфлікти & 22 & 26 & 18 & 17 & 11 \\
\hline СНІД & 24 & 22 & 25 & 23 & 22 \\
\hline Всі види забруднення довкілля & 4 & 2 & 5 & 8 & 3 \\
\hline Безробіття & 17 & 20 & 17 & 4 & 4 \\
\hline Підвищення цін & 3 & 13 & 1 & 2 & 1 \\
\hline Зниження рівня життя & 1 & 8 & 2 & 3 & 2 \\
\hline Відсутність або нестача необхідних харчів & 23 & 25 & 23 & 21 & 21 \\
\hline Використання їжі та води & 19 & 17 & 20 & 24 & 26 \\
\hline Хімічна промисловість & 10 & 16 & 15 & 12 & 17 \\
\hline Атомна промисловість & 12 & 15 & 13 & 15 & 19 \\
\hline Вугільна промисловість & 27 & 21 & 22 & 28 & 29 \\
\hline $\begin{array}{l}\text { Наявність хімічних речовин } \\
\text { - в повітрі }\end{array}$ & 5 & 6 & 8 & 5 & 12 \\
\hline - в воді & 6 & 3 & 3 & 6 & 9 \\
\hline - в грунті & 9 & 4 & 9 & 11 & 16 \\
\hline - в продуктах & 2 & 5 & 4 & 1 & 8 \\
\hline $\begin{array}{l}\text { Хвороби, пов’язані з наявністю в оточуючому } \\
\text { середовищі хімічних речовин }\end{array}$ & 7 & 1 & 10 & 7 & 10 \\
\hline $\begin{array}{l}\text { Наявність радіоактивних речовин } \\
\text { - в повітрі }\end{array}$ & 14 & 9 & 14 & 9 & 15 \\
\hline - в воді & 13 & $\overline{12}$ & 6 & 13 & 13 \\
\hline - в грунті & 15 & 7 & 11 & 14 & 14 \\
\hline - в продуктах & 11 & $\mathbf{1 0}$ & 12 & 16 & 6 \\
\hline $\begin{array}{l}\text { Хвороби, пов’язані з наявністю в оточуючому } \\
\text { середовищі радіоактивних речовин }\end{array}$ & 8 & 11 & 7 & $\mathbf{1 0}$ & 7 \\
\hline Особисті проблеми та турботи & 21 & 23 & 21 & 25 & 24 \\
\hline
\end{tabular}


радіаційної загрози в II групі (81,54\%), де респонденти зазнали ризику опромінення та евакуації в результаті аварії на ЧАЕС. В групі учасників АТО 31,34\% осіб з гіпертрофованим сприйняттям радіаційної загрози.

В структурі соціально-психологічного опитувальника респондентам основних груп, групи порівняння та учасникам АТО була запропонована «Анкета оцінки небезпек», де опитувані оцінювали рівень небезпеки для них та їхніх сімей серед екологічних, побутових, соціально-економічних факторів (безробіття, підвищення цін, вугільна промисловість, куріння та ін.), загалом 31 фактор за 5-бальною шкалою (1 - зовсім безпечно, 5 небезпека дуже велика). Як видно з таблиці 5, актуальний на даний момент фактор «національні конфлікти» займає серед груп постраждалих внаслідок аварії на ЧАЕС 22, 26 та 18-е рангове місце, в групі порівняння 17-е, в той час як серед учасників АТО - 11-е місце. Однак висока занепокоєність учасників АТО таким радіаційнім фактором, як хвороби, пов'язані з наявністю в навколишньому середовищі радіоактивних речовин (7-е рангове місце) при використанні «брудної бомби»на теритоpiї проведення АТО можуть спричинити додатковий травмуючий вплив на учасників АТО та посилити дезадаптивні реакції і патологічні зміни у особистості. Присвоєння високого рівня небезпек радіаційним факторам опитуваними I, II та III груп говорить про актуальність для них такої стресової події в їхньому житті, як катастрофа на ЧАЕС.

Звертає увагу на себе той факт, що в усіх групах, опитаних небезпечні фактори куріння та вживання алкоголю, займають останні рангові місця. В той час як відсоток курців серед АТО складає 73,77\%, серед УЛНА $28,32 \%$, серед УЛНА - евакуйованих $16,92 \%$, евакуйованих $-5,49 \%$, в групі порівняння $-46,75 \%$. Осіб які не вживають алкоголь серед АТО лише 13,56\%, серед УЛНА 19,64 , серед УЛНА - евакуйованих - 22,58\%, серед евакуйованих $-8,79 \%$, в групі порівняння $-20,78 \%$.

Гіпертрофоване сприйняття радіаційної загрози в групах УЛНА та евакуйованих із зони відчуження корелює з підвищенням занепокоєння з приводу атомної промисловості, наявністю радіоактивних речовин у повітрі, грунті, харчах $(\mathrm{p}<0,001)$. Неадекватне сприйняття радіаційного ризику корелює і зі ступенем психологічного стресу від Чорнобильської аварії (в усіх групах $\mathrm{p}<0,001$ ), ступенем психологічного стресу від евакуації (II $\mathrm{p}<0,001$, III $\mathrm{p}<0,01)$, занепокоєнням з приводу можливих аварій і несправностей у даний час на ЧАЕС (I та II $p<0,001$, III $p<0,05$ ); із занепокоєнням щодо впливу радіації на здоров'я $(\mathrm{p}<0,001)$, соціальними змінами $(\mathrm{p}<0,001)$ та негативними змінами в економічній ситуації у зв’язку з Чорнобильською аварією ( $<<0,001)$.

Висновки та перспективи подальшого дослідження: 
Проблеми радіаційної безпеки після Чорнобильської аварії бентежать та сприймаються як високо значущими різними групами населення. Радіаційна аварія представляє собою психічну травму зі складною конфігурацією травматичних впливів, які виходять за рамки звичайного людського досвіду. Формуючі травматичний стрес вона може призводити до психічних порушень, соматичних захворювань, знижувати адаптаційні можливості постраждалих.

Високий відсоток осіб з гіпертрофованим сприйняттям радіаційної загрози серед УЛНА та евакуйованих із зони відчуження свідчить про актуальність для них таких стресових подій в їхньому житті, як катастрофа на ЧАЕС та евакуація. Значний відсоток таких осіб в групі порівняння та серед учасників ATO говорить про наявність дистресу у всього населення країни з приводу іонізуючого опромінення.

Отримані дані дадуть змогу прояснити толерантність до радіаційного фактора, прогнозувати соціальну дезадаптацію та сприятимуть вибору психотерапевтичних програм. А також сприятимуть оптимізації критеріїв профвідбору, осіб, які будуть залучені до ліквідації наслідків радіаційних аварій.

\section{Перелік використаних джерел:}

1. Буртовая Е. Ю. Психосоциальные аспекты переселения жителей села Муслюмово Челябиской области вследствие чрезвычайных ситуаций на производствен- ном объединении «Маяк»/ Е.Ю. Буртовая, А.В. Аклеев, С.А. Шалагинов // Медико-биологические и социальнопсихологические проблемы безопасности в чрезвычайных ситуациях. - 2011. - №2. - С. 105 - 108.

2. Дворянчиков Н. В. Особенности восприятия и переживания «невидимого» стресса военнослужащими, работающими с источниками ионизирующих излучений/ Н.В. Дворянчиков, Н.В. Стариченко, С.Н. Ениколопов // Журнал практического психолога. - 2005. Вып. 1. - С. 49 - 63.

3. Моляко В. А. Формирование образа экологической катастрофы на примере Чернобыльской атомной аварии / В.А. Моляко // Вопр. психол. - 1992.- №5-6. - С. $16-22$.

4. Моляко В. О. Психологічні наслідки чорнобильскої катастрофи/ В.О. Моляко // Збірник наукових праць Інституту психології ім. Г.С. Костюка АПН України» Актуальні проблеми психології» у 12 томаї / за ред. В.О. Моляко. - Т12. - Вип. 12 - Житомир: вид-во ЖДУ ім. І. Франка, 2010. - С. $8-21$.

5. Павленко Т. О Вимоги до організації просвітницької роботи 3 населенням щодо радіаційних ризиків опромінення /Павленко Т.О., Аксьонов М.В., Фризюк М.А., Турос О.І., Герман О.О. //Гігієна населених місць. 2011. - №57. - С. 276- 279.

6. Прилипко В. A Екологічні та соціальні фактори ризику у формуванні здоров`я населення / Прилипко В.А., Озерова Ю.Ю., Пустовіт І. // І-й Всеукраїнський з’їд екологів: міжнар. наук.-техн. конф.: тези допов. 2006. C. 325 .

7. Румянцева Г. М. Проблемы восприятия и субъективной оценки риска от ионизирующей радиации / Г.М. Румянцева, О.В. Чинкина //Радиационная гигиена. Т2№3 - 2009. С. 50 - 58.

8. Социальное самочувствие населения в условиях повышенного экологического риска (По результатам Чернобыльской аварии). Научный доклад / РАН. Ин-т социологии. Центр общечеловеческих ценностей. М., 1992.

9. Тарасюк О. Є. Рівень знань щодо радіаційного фак- 
тора та сприйняття радіаційного ризику молоддю міста Славутич / О.С. Тарасюк, І.П. Лось, Н.Д. Шабуніна, T.С. Нездемовська //Enviroxment Health. - 2013 - №1, - С $33-38$.

10. Чинкина О. В. Радиационная авария как психическая травма: психологическая переработка воздействия на отдаленном этапе / О.В. Чинкина // Архів психіатрії. - 2011. - № 1(64), C. 21 - 26.

11. Bromet E. J. Emotional consequences of nuclear power plant disasters / E.J. Bromet // Health Phys. - 2014. Vol.106, no.2. - P. $206-10$.

12. Bromet E. J. Psychological and perceived health effects of the Chernobyl disaster: a 20-year review / E.J. Bromet, J.M. Havenaar // Health Phys. - 2007. - Vol.5. P. 516-21.

13. Perko T. Radiation risk perception:a discrepancy between the experts and the general population. / T. Perko // J Environ Radioact. - 2014. - Vol. 133. - P. 86 - 91.

14. Suzuki Y. Psychological distress and the perception of radiation risks: the Fukushima health management survey / Y. Suzuki at all // Bull World Health Organ. - 2015. Vol.93. - P. $598-605$.

\section{References (Transliteration):}

1. Burtovaya E. Yu Psihosotsialnyie aspektyi pereseleniya zhiteley sela Muslyumovo Chelyabiskoy oblasti vsledstvie chrezvyichaynyih situatsiy na proizvodstvennom ob'edinenii «Mayak»/ E.Yu. Burtovaya, A.V. Akleev, S.A. Shalaginov // Mediko-biologicheskie i sotsialnopsihologicheskie problemyi bezopasnosti V chrezvyichaynyih situatsiyah. - 2011. - №2. - S. 105 108.

2. Dvoryanchikov $N$. $V$. Osobennosti vospriyatiya i perezhivaniya «nevidimogo» stressa voennosluzhaschimi, rabotayuschimi s istochnikami ioniziruyuschih izlucheniy/ N.V. Dvoryanchikov, N.V. Starichenko, S.N. Enikolopov // Zhurnal prakticheskogo psihologa. - 2005. - Vyip. 1. - S. $49-63$.

3. Molyako $V$. A. Formirovanie obraza ekologicheskoy katastrofyi na primere Chernobyilskoy atomnoy avarii / V.A. Molyako // Vopr. psihol. - 1992.- №5-6. - S. 16-22.

4. Molyako V. O. Psihologichni naslidki chornobilskoyi katastrofi/ V.O. Molyako // ZbIrnik naukovih prats Institutu psihologiyi Im. G.S. Kostyuka APN UkraYini» Aktualni problemi psihologiyi» u 12 tomaYi / za red. V.O. Molyako. - T12. - Vip. 12 - Zhitomir: vid-vo ZhDU Im. I. Franka, 2010. - S. $8-21$.

5. Pavlenko T. O Vimogi do organIzatsiy prosvitnitskoyi roboti $\mathrm{Z}$ naselennyam schodo radiatsiynih rizikIv opromInennya /Pavlenko T.O., Aksonov M.V., Frizyuk M.A., Turos O.I., German O.O. //Gigiena naselenih mIsts. - 2011. - №57. - S. 276- 279.

6. Prilipko V. A Ekologichni ta sotsialni faktori riziku u formuvannI zdorov`ya naselennya / Prilipko V.A., Ozerova Yu.Yu., PustovIt I. // I-y Vseukrayinskiy z'yizd ekologiv: mizhnar. nauk.-tehn. konf.: tezi dopov. 2006. - S. 325.

7. Rumyantseva G. M. Problemyi vospriyatiya i sub'ektivnoy otsenki riska ot ioniziruyuschey radiatsii / G.M. Rumyantseva, O.V. Chinkina//Radiatsionnaya gigiena. T2 - №3 - 2009. S. 50 - 58 .

8. Sotsialnoe samochuvstvie naseleniya $\mathrm{v}$ usloviyah povyishennogo ekologicheskogo riska (Po rezultatam Chernobyilskoy avarii). Nauchnyiy doklad / RAN. In-t sotsiologii. Tsentr obschechelovecheskih tsennostey. M., 1992.

9. Tarasyuk O. E. Riven znan schodo radiatsiynogo faktora ta spriynyattya radiatsiynogo riziku moloddyu mista Slavutich / O.E. Tarasyuk, I.P. Los, N.D. ShabunIna, T.E. Nezdemovska //Enviroxment Health. - 2013 - №1, - S 33 -38 .

10. Chinkina $O$. $V$. Radiatsionnaya avariya kak psihicheskaya travma: psihologicheskaya pererabotka vozdeystviya na otdalennom etape / O.V. Chinkina // ArhIv psihIatrIYi. - 2011. - № 1(64), S. 21 - 26.

11. Bromet E. J. Emotional consequences of nuclear power plant disasters / E.J. Bromet // Health Phys. - 2014. Vol.106, no.2. - P. $206-10$.

12. Bromet E. J. Psychological and perceived health effects of the Chernobyl disaster: a 20-year review / E.J. 
Bromet, J.M. Havenaar // Health Phys. - 2007. - Vol.5. P. 516-21.

13. Perko T. Radiation risk perception:a discrepancy between the experts and the general population. / $\mathrm{T}$. Perko // J Environ Radioact. - 2014. - Vol. 133. - P. 8691.

14. Suzuki Y. Psychological distress and the perception of radiation risks: the Fukushima health management survey / Y. Suzuki at all // Bull World Health Organ. - 2015. Vol.93. - P. 598- 605.

\section{Hresko Maryna}

Junior researcher in The Department of Radiation Psychoneurology of The State Institution «National Research Center for Radiation Medicine of National Academy of Medical Sciences of Ukraine», Kiev (Ukraine)

\section{PSYCHOLOGICAL FEATURES OF RADIATION RISK PERCEPTION}

\section{ABSTRACT}

The purpose of the study was to determine the subjective features of the perception of radiation risk and to determine its place among other hazards in the remote period after the Chernobyl disaster.

Object and methods: Participated in the study: 122 liquidators (group 1); 76 liquidators, who were also evacuated from the exclusion zone (group 2); 118 people evacuated from the exclusion zone (group 3). The comparison group was 84 people (group 4). 81 participants of the ATO (5 - group) were also interviewed.

Results of the study: In the comparison group, significantly less $(p<0.001)$ fewer persons with hypertrophied perception of radiation threat compared to the main groups. The highest per- centage of respondents with hypertrophied perception of radiation threat are in group II $(81,54 \%)$, where respondents were exposed to the risk of exposure and evacuation as a result of the Chernobyl accident. In the group of ATO participants there are $31,34 \%$ of persons with hypertrophied perception of radiation threat.

The actual "national conflicts" factor currently occupies among the groups affected by the Chernobyl accident: 22nd, 26th and 18th ranked place, 17th in the comparison group, while among the participants of the ATO - 11th place. However, the high concern of ATO participants with such a radiation factor as the diseases associated with the presence of radioactive substances in the environment (rank 7), caused by using a "dirty bomb" in the territory of the ATO, can lead to additional traumatic effects on ATO participants and will intensify the maladaptive reactions. A high assessment of the radiation hazard of the I, II and III groups interviewed, indicates the relevance for them of such a stressful event in their life as an accident at the Chernobyl nuclear power plant.

The hypertrophied perception of the radiation threat in groups of liquidators and evacuees from the exclusion zone correlates with heightened concern about the nuclear industry, the presence of radioactive substances in air, soil, and products $(p<0,001)$. Inadequate perception of radiation risk correlates with the degree of psychological stress from the Chernobyl accident (in all groups $p<0.001$ ), the degree of psychological 
stress from evacuation (II $p<0,001$, III $p<0,01$ ), concern about possible accidents and malfunctions to this time at the Chernobyl nuclear power plant (I and II $p<0,001$, III $p<0,05$ ) with concern about the effect of radiation on health $(p<0,001)$, social changes $(p<0,001)$ and negative changes in the economic situation due to the Chernobyl accident $(\mathrm{p}<0,001)$.

Conclusions: Problems of radiation safety after the Chernobyl accident disturb all respondents and are perceived as highly significant by different groups of the population. Radiation accident is a mental trauma with a complex configuration of traumatic effects that go beyond the limits of ordinary human experience. The obtained data will help to predict social disadaptation and will contribute to the creation of psychocorrectional and psychotherapeutic programs.

Keywords: perception of radiation threat, clean-up workers (liquidators) of the Chernobyl accident, participants in the antiterrorist operation (ATO).

\section{Гресько Марина Владимировна}

Младиий научный сотрудник отдела радиационной психоневрологии Государственного учреждения «Национальный научный цеентр радиационной медицины Национальной академии медицинских наук Украиныл», г. Киев (Украина)

\section{ПСИХОЛОГИЧЕСКИЕ ОСОБЕННОСТИ ВОСПРИЯТИЯ РАДИАЦИОННОГО РИСКА}

Аннотация. Цель исследования: Определение субъективных особенностей восприя- тия радиационного риска и определение его места среди других опасностей в отдаленный период после аварии на ЧАЭС.

Объект и методы: В исследовании приняли участие 122 участника ликвидации последствий аварии на ЧАЭС (1 - группа); 76 УЛПА на ЧАЭС, которые к тому же были эвакуированы из зоны отчуждения (2 - группа); 118 человек эвакуированных из зоны отчуждения (3 - группа). Группу сравнения составили 84 человека (4 - группа). Также было опрошено 81 участника ATO (5 - группа).

Результаты исследования: В группе сравнения достоверно ( $<0,001)$ меньше лиц с гипертрофированным восприятием радиационной угрозы по сравнению с основными группами. Наибольший процент респондентов с гипертрофированным восприятием радиационной угрозы во II группе $(81,54 \%)$, где респонденты подверглись риску облучения и эвакуации в результате аварии на ЧАЭС. В группе участников АТО 31,34\% лиц с гипертрофированным восприятием радиационной угрозы.

Актуальный на данный момент фактор «национальные конфликты» занимает среди групп пострадавших вследствие аварии на ЧАЭС: 22, 26 и 18 ранговое место, в группе сравнения 17, в то время как среди участников АТО - 11 место. Однако высокая озабоченность участников АТО таким радиационным фактором, как болезни связанные с наличием в окружающей среде радиоактивных веществ 
(7 ранговое место) при использовании «грязной бомбы» на территории проведения АТО может вызвать дополнительное травмирующее воздействие на участников АТО и усилит дезадаптивные реакции. Высокая оценка радиационной опасности опрошенными I, II и III групп, говорит об актуальности для них такого стрессового события в их жизни, как авария на ЧАЭС.

Гипертрофированное восприятие радиационной угрозы в группах УЛНА и эвакуированных из зоны отчуждения коррелирует с повышенным беспокойством по поводу атомной промышленности, наличием радиоактивных веществ в воздухе, почве, продуктах $(\mathrm{p}<0,001)$. Неадекватное восприятие радиационного риска коррелирует и со степенью психологического стресса от Чернобыльской аварии (во всех группах p<0,001), степенью психологического стресса от эвакуации (II $\mathrm{p}<0,001$, III $\mathrm{p}<0,01)$, беспокойством по поводу возможных аварий и неисправностей в данное время на ЧАЭС (I и II $\mathrm{p}<0,001$, III $\mathrm{p}<0,05$ ) с беспокойством о влиянии радиации на здоровье $(p<0,001)$, социальными изменениями $(\mathrm{p}<0,001)$ и негативными изменениями в экономической ситуации в связи с Чернобыльской аварией $(\mathrm{p}<0,001)$.

Поэтому проблемы радиационной безопасности после Чернобыльской аварии тревожат всех опрошенных и воспринимаются как высоко значимые различными группами населения. Радиационная авария представляет собой психическую травму со сложной конфигурацией травматических воздействий, которые выходят за рамки обычного человеческого опыта. Полученные данные помогут прогнозировать социальную дезадаптацию и будут способствовать созданию психокоррекционных и психотерапевтических программ.

Ключевые слова: восприятие радиационной опасности, участники ликвидации аварии на ЧАЭС (УЛПА), участники антитеррористической операции (АТО).
Дата отримання статті: 16.12 .2017

Дата рекомендації до друку: 20.12.2017 